\title{
A NEW PERSPECTIVE ON FISCAL DECENTRALIZATION
}

\begin{abstract}
In today's world, fiscal decentralization is a multidimensional phenomenon, which has different effects on interregional relations and national economy, both developing and developed countries. Especially many developing and transition countries attribute a great meaning to fiscal decentralization in order to produce resolution for economic problems, to prevent of corruption and to provide efficiency in public services. In order to obtain expected utility from fiscal decentralization, there is also needed a multidimensional theoretical approach. This paper, which is prepared as a literature review, intends to describe the general framework of fiscal decentralization with a new theoretical perspective. The sub-goal of this paper is to review the casual relationship between fiscal decentralization and governance indicators.
\end{abstract}

Keywords: fiscal decentralization; fiscal federalism; local authority; economic growth; accountability.

\section{Introduction}

The last quarter of the $20^{\text {th }}$ century -especially during the 1980s (Schneider, 2003) - a growing number of countries around the world have embarked on fiscal decentralization programs consisting of reallocating expenditure functions, devolving revenue sources, and serving local public services from local authorities and central governments (Mello, 2000). In connection with the worldwide growing interest in fiscal decentralization, the countries in transition of Eastern Europe -especially former Soviet States- and some of the developing countries experienced the different various of fiscal decentralization in order to reorganizing administrative systems, escaping from the traps of inefficiency, maintaining macroeconomic stabilization, and providing economic growth (Bird, 1993). Accordingly, fiscal decentralization problematic has also 
been on the policy agendas of most OECD countries (Martinez-Vazquez and $\mathrm{McNab}, 1997)$.

In the context of fiscal decentralization practices, while some of the country experiences gave positive results, but some of them could not go beyond to being an application fail. In this respect, today, fiscal decentralization has worked well in some developed countries -such as Germany, Austria, United States, the Scandinavian Countries- and some developing countries -such as Indonesia, Malaysia and India. However it has not work desirably in some other undeveloped and developing countries - such as Argentina and Brazil (Tanzi, 1996). According to this information, it is possible to say that today developed countries are generally more decentralized and some of the Latin American countries decentralized over the period from 1980 to 1995 (Epple and Nechyba, 2004).

Fiscal decentralization is not a monotonic and static approach. As a result of its dynamic nature, the countries that have a different development level tended to fiscal decentralization in connection with their conditional expectations. If we take a glance at some of the specific country practices, as an example of good practice, the benefits to be derived from the fiscal decentralization will be more clearly understood. For instance, in Canadian practice the threat of national disintegration -Quebec issue- has led the fiscal decentralization movement. In Germany, fiscal decentralization became a necessity in connection with unification issue. In United States practice, which was known as new-federalism, has resulted from the meeting the fiscal competition and fiscal equalization (Bird, 1993; Gramlich, 1993).

In this theoretical study we begin with a brief conceptional overview regarding fiscal federalism and fiscal decentralization. In the sequel, this study proceeds with an evaluation on the nature, scope, benefits, dangers, and causing factors of the fiscal decentralization. In connection with this theoretical information, the importance of corruption and economic growth should be considered on a preferential basis. Accordingly, in the final section of this study, the relationship between fiscal decentralization and corruption and economic growth will be separately revealed in the light of the theoretical and empirical literature.

In this paper, the term "local authority" and/or "subnational government" include all levels of government below the national level. In this respect, these terms can be defined as states, provinces, cities, municipalities, cantons, and 
communes depending on the governmental system and/or model such as federal state, unitary state, and regional state. The term "central government" will be used to describe national (federal, unitary, and regional state) tiers of government.

\section{Concept of Fiscal Federalism and Fiscal Decentralization}

Fiscal decentralization, which is the one financial classification criteria of the local authorities, cognitively associates with different terms. In this context, the currently alternative terms can be indicated as "fiscal federalism", "fiscal autonomy", "financial localization", "financial sovereignty", and "decentralized fiscal system". As a subfield of public economics, fiscal federalism is the most important and well-known term that implies to the fiscal decentralization, which is often used by European and American writers (Davey, 2003).

There is no unique definition on the fiscal federalism, which is involve the relations of multilevel governments (Tiebout, 1961), due to the different forms of the federalism around the world. Additionally, the fiscal and economic usage of the term "federalism" is quite different from its standard usage in political science. In fact, Oates (1999) stated that the choice of the term "fiscal federalism" was an unfortunate. Even tough, this non-unique situation and term delinquency, it is possible to define fiscal federalism in the general manner for the definition of the fiscal federalism. According to Oates (1999) fiscal federalism "(...) addresses to the vertical structure of public sector (...) and it explores both in normative and positive terms, the roles of the different levels of government and the ways in which they relate to one another through such instruments as intergovernmental grants" (Oates, 1999, p. 1120).

Even if fiscal decentralization evaluated as the sub-element of the fiscal federalism, Tiebout (1961) considered these terms as the same manner. In connection with the fiscal federalism, fiscal decentralization can be defined and explained in the light of the prime authors definition.

Oates describes fiscal decentralization "as a mechanism to make policy more responsive to local needs and to involve the local populace in processes of democratic governance" (Oates, 1993, p. 238). According to Tanzi (1996); "fiscal decentralization exists when subnational governments have the power, given to them by the constitution or by particular laws, to raise (some) taxes and carry out spending activities within clearly established legal criteria" (Tanzi, 
1996, p. 297). As noted by Mello (2000) “fiscal decentralization consists primarily of devolving revenue sources and expenditure functions to lower tiers of government" (Mello, 2000, p. 365). Mello and Barenstein (2001) describe fiscal decentralization as "the assignment of expenditure and revenue mobilization functions to subnational levels of government" (Mello and Barenstein, 2001, p. 1). One of the last studies Davey (2003) describes fiscal decentralization as "the division of public expenditure and revenue between levels of government, and the discretion given to regional and local government to determine their budgets by levying taxes and fees and allocating resources" (Davey, 2003, p. 8). According to Falleti (2005) "fiscal decentralization refers to the set of policies designed to increase the revenues or fiscal autonomy of subnational governments. Fiscal decentralization policies can assume different institutional forms such as an increase of transfers from the central government, the creation of new subnational taxes, or the delegation of tax authority that was previously national" (Falleti, 2005, p. 329). Roy (2008) defined fiscal decentralization as "the process of transferring budgetary authority from central government to elected subnational governments in order to grant them power to make decisions regarding taxes and expenses" (Roy, 2008, p. 3). As Bodman et al. (2009) explained, "fiscal decentralization, the devolution of fiscal responsibilities and power from the national government to subnational governments." (Bodman et al., 2009, p. 2).

In the light of these definitions, the main elements of the fiscal decentralization can be classified as follow:

- to address local needs and preferences;

- to predict a new macroeconomic mechanism and policy;

- to redistribute national, interregional, and subnational relations;

- to provide a multidimensional vision on public economics;

- to mention devolution or delegation of the revenue, expenditure, and budget authority.

\section{Nature of Fiscal Decentralization}

Nature of fiscal decentralization can be determined on the contextual, definitional, focal, legal, governmental, and theoretical manner.

As the contextual manner, fiscal decentralization refers to how much central governments renounce its power in favor of local authorities (Schneider, 2003). 
The success of fiscal decentralization requires a clear and effective delegation of functions and resources between the local authorities and central governments (Rodríguez-Pose and Krøijer, 2009). In this context, fiscal decentralization covers the division of spending responsibilities, expenditure functions, and revenue sources between the local authorities and central governments and the power of discretion given to local authorities to determine their services and goods, expenditures, and revenues (Davey, 2003).

As the definitional manner, fiscal decentralization that increases the power of local authorities (Falleti, 2005) can be defined as a bureaucratic and judicial mechanism for constraining the interventionist tendencies of central governments (Porcelli, 2009). Fiscal decentralization requires decentralization of public expenditure functions such as power of the purse and revenue resources such as taxes, duties, fees, and the other financial obligations. As a result of the fiscal decentralization, fiscal policy-making power and authority transferred from central government to local authorities. The task of providing public goods and services and the other public sector functions are shared between central governments and local authorities (Mello, 2000).

As the focal manner, fiscal decentralization focuses on the maximizing and maintaining the social welfare, economic stability, economic efficiency, fiscal discipline, economic development and growth, distributive efficiency, administrative and financial accountability, fiscal transparency, and good governance (Schneider, 2003; Rodríguez-Pose and Krøijer, 2009).

As the legal manner, fiscal decentralization directly connected and strongly influenced by the legal system. In this context, in common law system fiscal decentralization could be integrated easily, due to the traditional practices. But however, in civil law system, which is based on hierarchy of norms, local authorities are merely local agents of the central government and fiscal decentralization could not easily integrated into administrative system as such in common law system (Tumennasan, 2005).

As the governmental manner, the nature of the fiscal decentralization can be expounded with the "delegation" and "devolution" terms. (1) First of all, delegation term presents a "top down" process in fiscal decentralization. In decentralization by delegation, expenditure function and tax collection power is given to local authorities by the central government according to the explicit norms and rules. These powers can be changed, limited and/or revoked by the central governments. It is possible to say that fiscal decentralization by 
delegation is suit for the unitary states. (2) Devolution term presents a "bottom up" process in fiscal decentralization. In decentralization by devolution, local authorities have a wide and permanent power/right on the expenditure and tax basis. For instance, these authorities can revoke, impose, and amend taxes, govern their own affairs, and formulate their expenditures with a little intervention by the central government. In this respect, fiscal decentralization by devolution is suit for the federalist states (Martinez-Vazquez and McNab, 1997).

As the theoretical manner, the fiscal decentralization theory basically is a sub-branch of public economics (Martinez-Vazquez and McNab, 1997). In this respect, fiscal decentralization has also being examined as a subfield of economy theory and public economics. In fact, in connection with the economy theory, Musgrave (1959) categorizes the economic functions of government as the allocation branch, the distribution branch, and the stabilization branch. In this classification, the allocation branch is directly connected with the production of public goods and services and it is mentioned decentralized provisions providing for the satisfaction of public wants both local authorities and central government (Musgrave, 1959). In addition to what is mentioned above, fiscal decentralization is directly associated with public choice theories. Various public choice theories, in order to reach the best matching of citizen and local resident preferences, explore the possibility of the resource and expenditure jurisdiction mobility in fiscal decentralization (Rodden, 2004).

\section{Scope of Fiscal Decentralization}

Identification of the scope of fiscal decentralization is quite important for the efficient service providing at the local level. For the sake of prevention double taxation and presentation efficient public service, fiscal decentralization can be evaluated within the scope of revenue resources, budget and expenditure function, public services and goods, and intergovernmental transfers.

\section{A. Revenue Resources}

The various levels of government require specific fiscal instruments in order to carry out their main functions and finance public expenditures (Oates, 1999). In general, local authorities and central governments are providing funds, as the fiscal instruments, from the same revenue resources. In such a case, determination and composition of local and central revenues become compulsory 
and necessary (Sakal et al., 2014) for the identification of the fiscal decentralizations revenue scope. First of all, today, revenue resources are composed of compulsory and non-compulsory resources.

(1) As a requirement and result of the principle of legality and the rule of law, compulsory resources are based on the sovereign right of a state. These resources are divided into two groups in their entirety. (a) In the first group, which can be named as taxation resources, composed of taxes, fees, duties and the other financial obligations. By the way, taxation resources comprise accessory obligations such as increases and tax penalties concerning national (central) and local obligations as well. (b) In the second group, parafiscal resources, public enterprises revenues, seignorage resources, and administrative and judicial fines generate other compulsory resources (Bilici \& Bilici, 2013).

(2) In contrast with the compulsory resources, non-compulsory resources are not based on the sovereign right of a state. In non-obligatory resources, when appropriate, principle of volunteerism can also be taken into consideration. In this respect, these resources can be evaluated as the voluntary resources as well. These resources can be indicated as public debts, public estate incomes, fiscal monopolies, donations and aids, and fund revenues (Edizdoğan et.al, 2011; Bilici and Bilici, 2013; Aksoy, 2011).

In fiscal decentralization, these kinds of revenue sources and their management authority, which can be defined as debt management and tax administration, are shared across levels of government (Mello, 2000). However, taxation resources and especially local taxes and their administrations are well-known and common scope of fiscal decentralization (Davey, 2013).

Today, local authorities need their own revenue resources and their administration authority in order to handle local needs and preferences (Oates, 1993). According to fiscal decentralization, if some of the revenue resource collection power transferred to local authorities, central governments fiscal impact will decrease equally (Schneider, 2003). But this power transfer should not harm the national sovereignty and unity.

\section{B. Budget and Expenditure Function}

In fiscal decentralization, local authorities have discretion right to govern their local budgets without intervention from the central government (Golem, 2010). In this respect, local authorities should have some revenue and expenditure determination power and budget making authority for successful fiscal 
decentralization. If these power and authority do not given to local authorities, they will not balance their budgets. As a result, local authorities need a budget authority in order to regulate both the expenditures and revenues (Roy, 2008).

In connection with the nature of the public services and goods, they are funded either by the central governments or by the local authorities budget (Davey, 2013). Expenditure function focuses on the amount of government activity (Schneider, 2003).

\section{Public Services and Goods}

Production of public goods and services are divided between local authorities and central governments. (1) According to this division, national public services and goods should be provided by the central governments to the entire population of the country. Additionally, national security, defense and justice services and connected other national goods and services are included within the responsibility of the central government (Oates, 1999). (2) However, some of the public services and goods are directly connected with the local needs and preferences, due to their regional or municipal benefit. In this respect, local authorities are especially responsible for rendering of communal services and goods. These services can be classified as regional transportation systems, local road lightening, street lightning, water supply, forestry services, public hygiene, waste management, parks and sports facilities, funerals and cemeteries services, and social responsibility projects (Davey, 2003; Tanzi, 1996). As it is seen, infrastructure investments are principally provided by the local authorities (Kappeler et al., 2012). (3) Finally, some of the public services are served together with local authorities and central governments. Basic health, social aid, fights against environmental pollution, public housing, and public education services can be considered within this scope (Öncel, 1998).

\section{Intergovernmental Transfers}

Intergovernmental transfers are so important for the local authorities in developing and/or transition countries, due to their limited taxing power. In these countries, local authorities' budget deficits are usually filled through the central government transfers. Additionally, based upon the wide disparities among the regions, central governments use transfers in order to equalize interregional differences. These transfers are useful tools that are encouraging local authorities to increase their spending functions with some of the external benefits. 
Finally, central governments collect taxes more cheaply and they distribute taxes effectively. Therefore, collected taxes are transferred between the local authorities (Roy, 2008).

\section{The Factors Causing the Emergence of Fiscal Decentralization}

Fiscal decentralization has emerged in public finances for a number of reasons. In this context, there is a basic and reasonable question needs to be answered: "What are the factors that led to the emergence of fiscal decentralization?" This question can be answered depending on the historical, national, international, and supranational perspective.

Factors at the historical perspective directly connected with the growing role of the public sector and developments in specific countries. (a) First of all, during and after the Great Depression and Second World War, public sector growth expeditiously in many countries (Tanzi, 1996), due to the heavy demands on central government. As a result of these social and political events, central governments took on its predominant role in the public sector (Oates, 1993). However, when the 1980's comes, the size and power of the central government has come under question. In connection with this questioning, a general perception occurred that less power should remain in the hands of the central government in favor of local authorities. After this historical development, some of the functions of central government devolved local authorities in order to ensure efficiency in public sector. (b) Secondly, the breakup of the Soviet Union opened a new door to the fiscal decentralization. After the breakup, many former Soviet States as well as developed centralist countries started to create fiscal arrangements from scratch and they needed to transfer some of the national responsibilities to local authorities. This situation that have started political and fiscal decentralization reforms in these countries was the logical outcome of the break up (Tanzi, 1996; Golem, 2010). (c) Finally, during the 1980's some of the developing countries -such as Brazil, Argentine, India, and Nigeria- faced various macroeconomic problems and even crisis. These problems and crisis also forced these countries to cut expenditures, to find new revenue sources, to use resources efficiency manner, and to make the financial systems more accountable. These competing factors were constrained these countries to decentralized their policy choices among the different level of governments (Tanzi, 1996). 
Factors at the national perspective directly connected with the proximity to local needs. Local authorities much closer to local people and geography and they possess knowledge of local preferences and cost conditions that central government is unlikely to have (Oates, 1999). Accordingly, local officials have more of the relevant local information than central government officials (Epple and Nechyba, 2004) because of the proximity. Therefore, they are the most important providers of local public goods and services due to their proximity to local needs. However, central governments are the main providers of the national public goods and services such as safety, justice, and defense services. Therefore, the local authorities should serve local public goods and services with their own revenue sources. As a result, if local authorities are considered as the most important providers of local public goods and services, it is necessary to give a remarkable share part of public revenues in order to bridge the gap between spending and revenues mobilized locally (Mello, 2000).

If we approach the factors causing the emergence of fiscal decentralization with a supranational perspective, European Union will be guide for us. Because of the European Integration Movement and its debate forced economists to look at the fiscal institutions of member countries with strong local authorities (Tanzi, 1996). But it is important to stress that; today EU is worry about fiscal decentralization due to the policy harmonization (Gramlich, 1993).

\section{Benefits of Fiscal Decentralization}

Although there is no full consensus on the benefits of fiscal decentralization (Lockwood, 2006), it is possible to establish the benefits through the conceptual approach. In this respect, efficiency, competition, governance, fiscal transparency and accountability, and economic welfare can help in order to identify the benefits of fiscal decentralization.

\section{A. Efficiency Benefit}

Local goods and services will be better matched the preferences of the residents of the localities (Lockwood, 2006). The allocative efficiency and public sector efficiency can be defined as the potential benefit and the sole objective of fiscal decentralization, due to the local needs and preferences are met in the best way by local level rather than national level. In other words, as a result of proximity and informational advantage, fiscal decentralization increases the 
public sector efficiency in public service delivery both local and national level and promotes resource allocative efficiency in the name of macroeconomic governance (Bird, 1993; Mello, 2000; Rodríguez-Pose and Krøijer, 2009). In addition to these, fiscal decentralization may imply greater consumer efficiency in public expenditures. Based upon different demands and preferences, revenue resources can be saved by differentiating governmental services and goods through the fiscal decentralization (Rodríguez-Pose and Krøijer, 2009). Finally it is important to stress that, theoretically and empirically there is no consensus on fiscal decentralization's affect on the total size of government, even though it brings about efficiency gains in the provision of public goods and services (Golem, 2010).

\section{B. Accountability, Fiscal Transparency and Governance Benefit}

Fiscal decentralization, as the policy instrument, might improve accountability, fiscal transparency and good governance (Lockwood, 2006; Mello and Barenstein, 2001; Mello, 2000). In this respect, if expenditure and revenue authority transferred to the local authorities envisioned in fiscal federalism theory, fiscal decentralization will bring local authorities closer to the citizens (Rodden, 2004). This proximity consequently makes it easier for citizens to get information about governmental activities and decisions (Karlström, 2015). As a result, fiscal decentralization enhances accountability and fiscal transparency in public service delivery and policy-making process (Mello, 2000). But however, it is important to stress that, being proximity to local communities and residents may also make adverse effects on accountability. In fact, proximity at the local level might make it easier to social and political influences on the local authorities. These influences might improve corrupt behavior and reduce accountability (Karlström, 2015).

Secondly, in connection with the correlation between the governance quality indices and composition of government expenditures (Huther and Shah, 1998), fiscal decentralization is positively correlated with good governance. Fiscal decentralization can reduce and operate the aggregate government expenditures, if the responsibilities of local and central level decision-makers will be defined clearly (Porcelli, 2009). Finally there is a clear and direct linkage between fiscal decentralization and democratic governance (Martinez-Vazquez and $\mathrm{McNab}$, 1997). In this relationship, especially fiscal decentralization has a significant effect on the democratic governance. Fiscal decentralization helps 
to deepen and strengthen democracy in connection with the devolution of the power from central government to local authorities (Falleti, 2005). Therefore, fiscal decentralization promotes democratic governance through the local accountability (Martinez-Vazquez, 2011).

\section{Competition Benefit}

Fiscal decentralization introduces fiscal competition among the local authorities relating to the tax collection power in order to maximize social welfare and deliver efficient public service (Porcelli, 2009; Golem, 2010). In fact, competition across local authorities will ensure the right matching of preferences between residents, local communities and local authorities (Rodríguez-Pose and Krøijer, 2009). "From a political economy perspective, competition may help control government size and solve the common pool problem" (Martinez-Vazquez, 2011). But however, it is important to stress that, according to Rodden (2014) “... neither .... decentralization nor federalism is a reasonable proxy for intergovernmental ... competition.” (Rodden, 2014, p. 495).

\section{Economic Welfare Benefit}

Fiscal decentralization increases economic welfare and government quality in connection with the local choices. However, economic welfare of the local public goods and services are varied as a result of differences in preferences and cost differentials (Oates, 1999; Martinez-Vazquez, 2011).

\section{The Dangers of Fiscal Decentralization}

It is important to stress that fiscal decentralization brings with it potential dangers, despite its remarkable benefits. In this respect, there are several uncertainties and difficulties that would be caused some of the dangers in practice. Identification of such dangers will allow preferring the realistic choices before the application of fiscal decentralization (Prud'homme, 1995). In this context, the dangers of fiscal decentralization can be listed as follow:

1. Fiscal decentralization requires greater complexity in intergovernmental fiscal relations. In connection with this complexity, it may cause some of the coordination failures in fiscal relations among the local and central authorities (Mello, 2000). 
2. Fiscal decentralization is face with some of the structural challenges. Tanzi (1996) explained challenges of decentralization on the insufficient information, corruption, low quality of local bureaucracy, technological change and increased mobility, and public expenditure management system.

3. In fiscal decentralization, a special attention should be given to fiscal transparency and clarity. Otherwise, fiscal relations among the local and central authorities may suffer from coordination failures. These failures may cause local authorities to spend resources inefficiently. Consequently, inefficiency induces a budgetary deficit and higher costs of borrowing (Mello, 2000).

4. Theoretically, fiscal decentralization is seen as a modern distributor and democratic tool for the sake of increasing democratic participation in the decision-making process (Rodríguez-Pose and Krøijer, 2009). But however, if a country's population structure is heterogenic and if ethnic, religious, racial, or other relevant characteristics are regionally distributed in a country (Tanzi, 1996), fiscal decentralization might increase the share of votes received by both regionalist and separatist parties. As a result, fiscal decentralization might jeopardize national unity and territorial integrity of the state (Bird et al., 2010; Martinez-Vazquez, 2011).

5. Fiscal decentralization has a potential benefit to increase the local participation. But however, this potential also incorporates a significant risk in developing countries. In fact, if the decision-making power does not spread and open to local residents, management and decision-making power may pass into the hands of a small privileged elite group. And this group may pursue their own interests to the detriment of the majority of local residents. As a result, a decentralized tyrant may replace instead of central government and fiscal decentralization may become just a formal practice (Oates, 1993; Martinez-Vazquez and McNab, 1997).

6. In developing countries, poor people live in low-income regions that offer fewer economic and infrastructure opportunities. This situation has adverse potential causing regional disparities. In order to reduce these disparities, national budgets are being used as important tools (Prud'homme, 1995). First of all, if the developmental disparities between the administrative and local regions do not eliminate, fiscal competition might reduce social welfare throughout the country (Porcelli, 2009). Secondly, if the devolution power will be left to the discretion of subnational officials (governors, 
mayors), fiscal decentralization might sharpen interregional and distributional conflicts and disparities (Falleti, 2005; Treisman, 1999).

7. Today, only the central governments use monetary policies and fiscal policies for stabilizing the economy, because local authorities have limited opportunities to undertake economic stabilization policies (Prud'homme, 1995). Thereby, local authorities cannot take an active part in stabilization of the national economy (Tanzi 1996) as such in central governments. "Local authorities will never provide enough economic stabilization; which must be conducted by central governments" (Prud'homme, 1995). Therefore, fiscal decentralization might have an adverse effect on the national macroeconomic health, because of its limitation on the central government's ability to use macroeconomic policy as a stabilization tool (Samuels, 2003). Especially in developing and transition economies, fiscal decentralization may have devastating consequences in terms of governance and economic stability. In this context, fiscal decentralization may increase public deficits, decrease government decision quality, stimulate interest groups' influences, and deepen interregional inequalities in developing and transition economies. In connection with governance indices, increasing subnational deficits lead to higher central governments expenditures and transfers. As a result of this rising in central government expenditures, fiscal decentralization may lead up higher inflation rates (Rodríguez-Pose and Krøijer, 2009).

\section{Corruption and Fiscal Decentralization}

Even if there is no complete consensus on the relationship between corruption and fiscal decentralization, various empirical research that are offer contradictory conclusions conducted in order to reveal this relationship (Treisman, 2000a). All of these research tries to find an answer on "How do fiscal decentralization affect the corruption opportunities and trends?" and "Can fiscal decentralization be a useful and effective tool to fighting against corruption?" In this respect, it will be useful to discuss these contradictory conclusions whether fiscal decentralization is associated with corruption.

According to Brueckner (1999), local corruption limits the benefits from fiscal decentralization in many developing countries. Goldsmith (1999) asserts that centralization associated with diminished corruption, anti-corruption 
reforms work better in centralized systems and federal or decentralized systems make easier to hide corrupt practices. Consequently, Goldsmith (1999) finds that there is a positive relationship between decentralization and corruption and a negative relationship between centralization and corruption. In other words, he suggests that decentralization have a negative effect in reducing corruption, but however centralization have a positive effect in reducing corruption. In support of Goldsmith's findings, Treisman (2000a; 2000b), by using Transparency International in Constructing Corruption Perception Index, also finds that perceived corruption is higher in federal countries.

Mello and Baresntein (2001) suggest that fiscal decentralization is associated with corruption and governance as well. They find that corruption can be diminished through the fiscal decentralization. In support of Mello and Barenstein's findings, Fissman and Gatti (2002), by using International Country Risk Guide Index, find that fiscal decentralization in government expenditure is remarkably associated with lower corruption and therefore decentralization is more effective in combatting corruption.

In contrast to Treisman and Goldsmith, Fisman and Gatti claim that there is a strong negative association between decentralization and corruption. Despite the contradictory empirical evidences and conclusions, interaction between corruption and fiscal decentralization has almost become a stubborn fact. Arikan (2004), by using a cross-country data set, find that fiscal decentralization negatively linked between fiscal decentralization, even if the empirical results are not particularly strong. In other words, she suggests that corruption is lower in the decentralized countries. In his dissertation Tumennasan (2005) find that fiscal decentralization can help to reduce and control corruption in public sector. But he indicated that not all of the aspects of fiscal decentralization have an equal effect on corruption.

Oto et al. (2013), by using International Country Risk Guide data for the 31 OECD member countries, find that decentralization may decrease the corruption by reducing fiscal deficits. They claimed that ".... bringing the government closer to the people is more useful or necessary when public administration is not working properly...." (Oto et al., 2013, p. 226). Albornoz and Cabrales (2013) empirically suggest that fiscal decentralization have a positive effect in reducing corruption under the influence of political competition conditions.

Freille et al. (2008) have reached an interesting result apart from the other research. In this context they, by using a dataset containing up to 174 developed 
and developing countries, find that fiscal decentralization is associated with lower corruption, but fiscal decentralization is associated with higher corruption in federalism.

Different form the above research, Karlström (2015), by using different decentralization indicators, finds that the relationship between fiscal decentralization and corruption depends on the democratic conditions. In this context, he concludes that fiscal decentralization promotes lower corrupt activities in democratic countries. But however, fiscal decentralization associated with higher corruption levels in authoritarian countries.

Apart from the empirical researches, there is also no a theoretical consensus about the explanation of this relationship. For instance, Rodden (2004) suggests that different types of decentralization have different causes and effects on corruption, due to the complexity and diversity of fiscal decentralization. Bardhan and Mookherjee (2006), on their literature review, suggest that theoretically fiscal decentralization can reduce corruption, even if these relationship complex. According to Lambsdorff (2006), "decentralization could be a means of reducing corruption by bringing government closer to the people." (Lambsdorf, 2006, p. 15). However Prud'homme (1995) suggest that the corruption is a great problem and even a remarkable danger at the local level.

Finally, it is clear to understand that, the relationship between fiscal decentralization and corruption still uncertain. But in our opinion, this relationship is in a multidimensional nature. Therefore, development levels, democratic and economic structures, and legal systems of the countries directly connected with the explanation of this relationship.

\section{Economic Growth and Fiscal Decentralization}

In recent decades, there has been a growing empirical literature that explores the relationship between fiscal decentralization and economic growth (Stansel, 2005). This relationship, on the empirical consensus, shows similarity with the corruption-decentralization relationship. In other words, even if there is no monotonic linkage between fiscal decentralization and economic growth, a lot of empirical and theoretical studies have been conducted in order to explain the potential linkage between the two (Martinez-Vazqeuz and McNab, 1997). These studies seek an answer on "What is the relationship between fiscal decentralization and economic growth?", "How does the fiscal decentralization 
affect the economic growth?", and "Can fiscal decentralization be a useful instrument for economic growth?" Even if there is no clear and definite answer to these questions, it is possible to handle different conclusions in a comparative perspective in the light of these questions.

First of all, Wallace Oates's arguments are very important for the explanation of this relationship. Oates (1993), with his theoretical study, supposes that there is strong connection between the decentralization and economic growth. According to Oates, fiscal decentralization improves the efficiency of government and encourages economic development and growth (Oates, 1993). Finally, Oates stress that; "The basic economic case for fiscal decentralization is the enhancement of economic efficiency: the provision of local outputs that are differentiated according to local tastes and circumstances results in higher levels of social welfare than centrally determined and more uniform levels of outputs across all jurisdictions." (Oates, 1993, p. 240).

Many fiscal decentralization theorists have supported Oates arguments. For instance, Bird (1993) and Gramlich (1993) have been supported Oates's arguments, about the relationship between economic growth and fiscal decentralization. It is important to stress that; Oates's arguments not only supported by the theorists but also mustered up support empirically. For instance, Lin and Liu (2000), using panel data for the provinces of China, find that fiscal decentralization has made a significant affect on economic growth and it can increase economic efficiency. Similarly, Akai and Sakata (2002), in a study specific to United States, find that fiscal decentralization have an significant effect on the economic growth. It is important to stress that, Akai and Sakata indicate that this finding do not provide an evidence on how fiscal decentralization contributes to economic growth, even though the positive relation between fiscal decentralization and economic growth suggestion. Stansel (2005), by using a data set of 314 United States metropolitan areas, find that decentralization enhances and promotes economic growth and development. According to Stansel, there is positive relationship between two phenomenons. Brueckner (2006), in conjunction with Oates (1993) claim, find that faster economic growth may constitute an additional benefit of fiscal decentralization.

Davoodi and Zou (1998), by using a cross-country panel data (GFS and BESD) set for 46 developed and developing countries, find that there is a negative relationship between fiscal decentralization and economic growth in developing countries. However they stated that the same finding does not apply 
to the developed countries. Similarly, Zhang and Zou (1998), by using a panel data for China, find that there is negative association between fiscal decentralization and economic growth. However, they found that fiscal decentralization makes a positive effect to local economic growth. Xie, Zou and Davoodi (1999), in a study specific to United States -by using various data sources such as ERP, HSUS, and HAUS etc, find that fiscal decentralization in public expenditures may be harmful for economic growth. Gemmell et al. (2009), by using dynamic panel dataset for 23 OECD member countries, find that fiscal decentralization negatively affect economic growth on the spending bases. However he indicate that revenue based fiscal decentralization positively affect economic growth. Rodriguez and Ezcurra (2010), by using GFC, AMECO and World Development Indicators for 21 OECD member countries, find that there is a significant negative association between fiscal decentralization and economic growth. Different from the Rodriguez and Ezcurra; Baskaran and Feld (2013), by using GFC for 23 OECD member countries, find that fiscal decentralization have an insignificant negative effect on economic growth.

Some of the researchers, different from the above, do not find a direct and homogenous relationship between fiscal decentralization and economic growth. Bodman et al. (2009), by using Bayesian Model Averaging (BMA) and times-series data for Australia, suggest that there is no straightforward relationship between fiscal decentralization and economic growth. Martinez and $\mathrm{McNab}$ (2006) find that decentralization may positively influence price stability in developing countries, but however it may negatively affect economic growth in developed countries. Similarly, Thornton (2007), from a crass section study of 19 OECD member countries, find that fiscal decentralization do not have significant and direct impact on economic growth. Hammond and Tosun (2009), by using times-series data for US counties, find that there is no homogenous impact of the fiscal decentralization on the economic growth.

\section{Conclusion}

Today, there is no unique and optimal fiscal decentralization practice because of its multidimensional nature. And still so many questions are waiting to be answered by the fiscal decentralization, even though there are a lot of theoretical and empirical studies. For instance, "Why do governments need fiscal decentralization?", "What is the connection between fiscal decentralization 
and democratic governance?", "Is fiscal decentralization a "cause" or a "result" of economic growth and corruption?". "Is fiscal decentralization increase local infrastructure investments?" "Is fiscal decentralization encouraged the strengthening of democratic institutions?", and "Is fiscal decentralization a matter of public choice or a product of supreme decision-making process?". It is possible to increase the number of these questions. These questions are meaningful for developed countries, because fiscal decentralization is fundamentally suitable for them. But however, there is a strong belief that fiscal decentralization incorporates some administrative and political threats due to structural problems in terms of developing and transition countries. At this point, the protection of national unity is particularly more important than the other benefits of fiscal decentralization in these types of countries. Finally, fiscal decentralization is reality for developed countries, but it is a dream that expected comes true for developing countries.

\section{Literature}

1. Akai N., Sakata M. (2002), Fiscal decentralization contributes to economic growth: evidence from state-level cross-section data for the United States, "Journal of Urban Economics", 52, pp. 93-108.

2. Aksoy Ş. (2011), Kamu maliyesi, Filiz Kitabevi, İstanbul.

3. Albornoz F., Cabrales A. (2013), Decentralization, political competition and corruption, "Journal of Development Economics", 105, pp. 103-111.

4. Arıkan G.G. (2004), Fiscal decentralization: a remedy for corruption?, "International Tax and Public Finance", 11, pp. 175-195.

5. Bardhan P., Mookherjee D. (2006). Decentralization, corruption and government accountabilit, [in:] S. Rose-Ackerman (ed.), International Handbook on the Economics of Corruption, Edward Elgar Publishing Ltd. Cheltenham, pp. 161-188.

6. Baskaran T., Feld L.P. (2013), Fiscal decentralization and economic growth in OECD countries: is there a relationship?, "Public Finance Review", 41(4), pp. 421-445.

7. Bilici N., Bilici A. (2013), Kamu maliyesi, Seçkin Yayıncılık, Ankara.

8. Bird R.M., (1993), Threading the fiscal labyrinth: some issues in fiscal decentralization, "National Tax Journal", 46 (2), pp. 207-227.

9. Bird R., Vaillancourt F., Roy-César É. (2010), Is decentralization "glue” or "solvent" for national unity?. International Studies Program Working Paper 10-03, Andrew Young School of Policy Studies - Georgia State University, Atlanta.

10. Bodman P., Heaton K., Hodge A. (2009), Fiscal decentralization and economic growth: a Bayesian model averaging approach, Macroeconomics Research Group. St. Lusia.

11. Brueckner J.K. (1999), Fiscal decentralization in developing countries: the effects of local corruption and tax evasion, CEMA Working Paper Series: Working Paper 1, pp. 1-18. 
12. Brueckner J.K. (2006), Fiscal federalism and economic growth, "Journal of Public Economics", 90, pp. 2107-2120.

13. Davey K. (2003), Fiscal decentralisation, Available from: http://unpan1.un.org/intradoc/ groups/public/documents/UNTC/UNPAN017650.pdf. (Accessed: 2th April 2016).

14. Davoodi H, Zou H. (1998), Fiscal decentralization and economic growth: a cross-country study, "Journal of Urban Economics", 43, pp. 244-257.

15. Edizdoğan N., Çetinkaya Ö., Gümüş E. (2011), Kamu maliyesi. Ekin Basın Yayın Dağıtım, Bursa.

16. Epple D., Nechyba T. (2004), Fiscal decentralization, [in:] J.V. Henderson, J.F. Thisse (eds.), Handbook of Regional and Urban Economics: Volume 4 Cities and Geography. Elsevier B.V. Amsterdam, pp. 2423-2480.

17. Falleti T.G. (2005), A sequential theory of decentralization: Latin American cases in comparative perspective, "American Political Science Review", 99 (3), pp. 327-346.

18. Fissman R., Gatti. R. (2002), Decentralization and corruption: Evidence across countries, "Journal of Public Economics", 83 (3), pp. 325-345.

19. Frielle S., Haque M., Kneller, R. (2008), Federalism, decentralisation and corruption, The Centre for Economic Policy Research, Available from: http://www.cepal.org/ilpes/ noticias/paginas/5/35065/Sebastian_Freille_Federalism_decentralisation_and_corruption. pdf. (Accessed: 14th April 2016).

20. Gemmell N., Kneller R., Sanz I. (2009), Fiscal Decentralization and Economic Growth in OECD countries: matching spending with revenue decentralization, Instituto de Estudios Fiscales. Available from: http://www.ief.es/documentos/recursos/publicaciones/ papeles_trabajo/2009_06.pdf. (Accessed: 13th January 2016).

21. Goldsmith A.A. (1999), Slapping the grasping hand: Correlates of political corruption in emerging market, "American Journal of Economics and Sociology", 58 (4), pp. 865-883.

22. Golem S. (2010), Fiscal decentralisation and the size of government: a review of the empirical literature, "Fiscal Theory and Practice", 34 (1), pp. 53-69.

23. Gramlich E.M. (1993), A policymaker's guide to fiscal decentralization, "National Tax Journal", 46 (2), pp. 229-235.

24. Hammond G.W., Tosun M.S. (2009), The impact of local decentralization on economic growth: evidence from U.S. counties, IZA Discussion Paper Series No: 4574, Bonn.

25. Huther J., Shah A. (1998). Applying a simple measure of good governance to the debate on fiscal decentralization, The World Bank Policy Research Working Paper: 1894.

26. Lambsdorff J.G. (2006) Causes and consequences of corruption: what do we know from a cross-section of countries?, [in:] S. Rose-Ackerman (ed.), International Handbook on the Economics of Corruption, Edward Elgar Publishing Ltd. Cheltenham, pp. 3-51.

27. Lin J.Y., Liu Z. (2000), Fiscal decentralization and economic growth in China, "Economic Development and Cultural Change", 49 (1), pp. 1-21.

28. Lockwood B. (2006), The political economy of decentralization, [in:] E. Ahmad, G. Brosio (eds.), Handbook of Fiscal Federalism, Edward Elgar Publishing Ltd. Cheltenham, pp. 33-60.

29. Kappeler A., Solé-Ollé A., Stephan A., Välilä T. (2012), Does fiscal decentralization foster regional investment in productive infrastructure?, DIW Berlin Discussion Paper-1024. Berlin. 
30. Karlström K. (2015), Decentralization, corruption and the role of democracy, Working Papers Series 2015: 14, QOG The Quality of Government Institute. Göteborg.

31. Martinez-Vazquez J., McNab R.M. (1997), Fiscal decentralization, economic growth and democratic governance, International Studies Program Working Paper 97-7, Andrew Young School of Policy Studies - Georgia State University, Atlanta.

32. Martinez-Vazquez J., McNab R.M. (2006), Fiscal decentralization, macrostability, and growth, "Hacienda Publica Española/Revista de Economía Publica", 179, pp. 25-49.

33. Martinez-Vazquez J. (2011), The impact of fiscal decentralization. Issues in theory and challenges in practice, Asian Development Bank. Manila.

34. Mello L.R.D. (2000), Fiscal decentralization and intergovernmental fiscal relations: A crass-country analysis, "World Development", 28 (2), pp. 365-380.

35. Mello L., Barenstein M. (2001), Fiscal decentralization and governance: a cross-country analysis, IMF Working Paper 01/71.

36. Musgrave R.A. (1959), The theory of public finance: A study in public economy. McGraw-Hill Book Company, New York.

37. Oates W.E. (1993), Fiscal decentralization and economic development, "National Tax Journal", 46 (2), pp. 237-243.

38. Oates W.E. (1999), An Essay of Fiscal Federalism, "Journal of Economic Literature", 37 (3), pp. 1120-1149.

39. Oto-Peralias D., Romero-Ávila D., Usabiaga C. (2013), Does fiscal decentralization mitigate the adverse effects of corruption on public deficit?, "European Journal of Political Economy", 32, pp. 205-231.

40. Öncel Y. (1998), Mahallî idareler maliyesi, Filiz Kitabevi, İstanbul.

41. Porcelli F. (2009), Fiscal decentralisation and efficiency of government: A brief literature review, Department of Economics, University of Warwick (UK). Available from: http://www2.warwick.ac.uk/fac/soc/economics/staff/fporcelli/dec_efficiency_gov.pdf. (Accessed: 12th April 2016).

42. Prud'homme R. (1995), The dangers of decentralization, "The World Bank Research Observer", 10 (2), pp. 201-220.

43. Rodden J. (2014), Comparative federalism and decentralization on meaning and measurement, "Comparative Politics", 36 (4), pp. 481-500.

44. Rodríguez-Pose A. and Krøijer A. (2009), Fiscal decentralization and economic growth in central and Eastern Europe, The London School of Economics and Political Science, LEQS Paper No. 12/2009. London.

45. Rodríguez-Pose A., Ezcurra R. (2010), Is fiscal decentralization harmful for economic growth? Edvidence from the OECD countries. Spatial Economics Research Centre, SERC Discussion Paper: 51, London.

46. Roy B. (2008), The pillars of fiscal decentralization. CAF Working Papers, Caracas.

47. Sakal M., Meriç M., Demirhan H. (2014), Mali Yerinden Yönetim Giriş ve Kavramsal Açıklamalar, [in:] M. Sakal, A. Kesik, T. Akdemir (eds.) Mali Yerinden Yönetim. Nobel Akademik Yayıncılık Eğitim Danışmanlık Tic.Ltd.Şti. Ankara, pp. 1-23.

48. Samuels D. (2003). Ambition, federalism, and legislative politics in Brazil, Cambridge University Press, Cambridge. 
49. Schneider A. (2003), Decentralization: conceptualization and measurement, "Studies in Comparative International Development", 38 (3), pp. 32-56.

50. Stainsel D. (2005), Local decentralization and local economic growth: a cross-sectional examination of US metropolitan areas, "Journal of Urban Economics", 57, pp. 55-72.

51. Tanzi V. (1996), Fiscal federalism and decentralization: a review of some efficiency and macroeconomic aspects, [in:] M. Bruno, B. Pleskovic (eds.), Annual World Bank Conference on Development Economic 1995, The International Bank for Reconstruction and Development/The World Bank. Washington D.C., pp. 295-316.

52. Thornton J. (2007), Fiscal decentralization and economic growth reconsidered, "Journal of Urban Economics", 61, pp. 64-70.

53. Tiebout C.M. (1961), An economic theory of fiscal decentralization. In A Conference of the Universities-National Bureau Committee for Economic Research (ed.). Public Finances: Needs, Sources, and Utilization, Princeton University Press, Princeton, pp. 79-96.

54. Treisman D.S. (1999), After the deluge - regional crises and political consolidation in Russia, The University of Michigan Press, Michigan.

55. Treisman D. (2000a), Decentralization and the quality of government. Department of Political Science, UCLA, Available from: https://www.imf.org/external/pubs/ft/seminar/2000/fiscal/treisman.pdf (accessed: 9 March 2016).

56. Treisman D. (2000b), The causes of corruption: A cross-national study, "Journal of Public Economics", 76 (3), pp. 399-457.

57. Tumennasan B. (2005), Fiscal decentralization and corruption in the public sector, Georgia State University Scholar Works, Lexington-Massachusetts.

58. Xie D., Zou H., Davoodi H. (1999), Fiscal decentralization and economic growth in the United States, "Journal of Urban Economics", 45, pp. 228-239.

59. Zhang T., Zou H. (1998), Fiscal decentralization, public spending, and economic growth in China, "Journal of Public Economics" 68, pp. 221-240.

Mehmet Alpertunga Avci Atatürk University Faculty of Law, Erzurum/TURKEY 